\title{
Planned reference and intervention levels in Finland
}

\author{
R. MUSTONEN
}

\begin{abstract}
In Finland, Radiation and Nuclear Safety Authority (STUK) is the competent authority and the national warning point with respect to bilateral and international agreements. STUK has drafted proposals for new guides for intervention levels in different phases of an emergency to be adopted by the Ministry of Interior (MoI) in Finland. These guides are written separately for early phase and intermediate phase of a radiological emergency. STUK selected $20 \mathrm{mSv}$ effective residual dose from all exposure pathways during the first year of an emergency as the reference level. This overall goal has been supplemented with the following general guidance; if a projected dose without protective measures is during the first year: (1) higher than $10 \mathrm{mSv}$, it is necessary to perform protective measures; radiation expose is dominant in decision making, (2) 1-10 mSv, protective measures are usually justified but other factors effect decision making, (3) below $1 \mathrm{mSv}$, the protective measures may be carried out especially if they are easily feasible; other factors are dominant in decision making. More specific criteria are given for separate countermeasures as a projected dose in a certain time period or as an operational intervention level (OIL) in a quantity which can be directly measured (external dose rate, magnitude of surface contamination, concentration level) or as a trigger (such as plant conditions). This paper presents the main intervention levels and criteria to be used in a radiological emergency for members of the public.
\end{abstract}

Keywords: Radiological emergency/intervention levels/criteria/public/decision making

\section{Introduction}

The International Commission on Radiological Protection (ICRP) revised its basic recommendations for a system of radiological protection in its Publication 103 (ICRP, 2007). The previous process-based protection approach using practices and interventions was replaced with an approach based on exposure situations, i.e. planned, emergency and existing situations. Application of the Commission's

STUK, Radiation and Nuclear Safety Authority, P.O. Box 14, 00881 Helsinki, Finland. 
recommendations for the protection of people in emergency and post-emergency existing exposure situations were later described in the ICRP Publications 109 and 111, respectively (ICRP 2009a, 2009b).

The reference level, introduced by the ICRP, represents the level of residual dose or risk above which it is generally judged to be inappropriate to plan to allow exposures to occur. Therefore, any planned protection strategy should at least aim to reduce exposures below this level, with optimisation achieving still lower exposures. Protection against all exposures, above or below the reference level, should be optimised. In the context of developing response plans for emergency exposure situations, the ICRP recommends that national authorities should set reference levels between $20 \mathrm{mSv}$ and $100 \mathrm{mSv}$ effective dose (acute or per year, as applicable to the emergency exposure situation under consideration). Reference levels below $20 \mathrm{mSv}$ may be appropriate for the response to situations involving low projected exposures. There may also be situations where it is not possible to plan to keep all doses below the appropriate reference level, e.g. extreme malicious events or lowprobability, high-consequence accidents in which extremely high acute doses can be received within minutes or hours. For these situations, it is not possible to plan to avoid such exposures entirely, and therefore, the ICRP advises that measures should be taken to reduce the probability of their occurrence, and response plans should be developed that can mitigate the health consequences where practicable. The best possible protection will be achieved by considering simultaneously all exposure pathways and all relevant protection options when deciding on the optimum course of action. Each individual protective measure must be justified by itself in the context of an overall protection strategy, but also the full protection strategy must be justified.

In addition to the reference level, the ICRP recommends to set, in advance, internally consistent dose criteria for protective actions that need to be taken promptly in order to be effective, and, based on these criteria, to derive appropriate triggers, expressed as readily measurable quantities, for initiating them in the event of an emergency (ICRP, 2009a). STUK has drafted proposals for new guides for intervention levels in different phases of an emergency in Finland (STUK, 2011). The new guides include the recommendations of the ICRP and also general guidance on performing protective measures based on the first-year projected individual dose. More specific criteria are given for categorizing a radiation situation and for separate countermeasures as a projected dose in a certain time period or as an operational intervention level (OIL) in a quantity which can be directly measured (external dose rate, magnitude of surface contamination, concentration level) or as a trigger (such as plant conditions). The new guides are submitted to the Ministry of Interior (MoI) to be adopted as the national regulations. This paper presents the main intervention levels and criteria to be used in a radiological emergency in Finland for members of the public. 


\section{Categories of a radiological emergency and a contamination level}

Especially during the intermediate phase, when selecting protective actions and the way to perform them, the benefits and disadvantages caused by the actions are assessed. There are many and various protective actions and combinations of them to be considered. In order to reduce exposure, the combined effect of the various actions will be taken into account. The choice of protective actions is also affected by their assumed duration: for example, a short-term evacuation carried out rapidly combined with decontamination of the environment is likely a better choice than a temporary relocation for months, because harm caused by the evacuation and decontamination is minor. Other than radiation protection arguments play an important role when taking long-term actions lasting several months or even years and therefore ask for a thorough assessment of factors before the decision. These factors are, for example, environmental, social, ethical, economical, psychological, cultural, political, etc. In a radiation situation where the exposure to radiation is small, these other factors have more impact on decision making than the exposure itself. In a severe radiation situation, where the radiation doses without any protective actions would be high, reducing the exposure is a dominant factor. In this case protective actions are needed even if they would cause a major harm to people's normal lives or significant economic costs.

The aim is that the residual dose would not exceed the chosen reference level during the first year, taking into account all radiation exposure pathways and protective actions. If the projected annual effective dose due to the radiation hazard without any protective actions is:

- higher than $10 \mathrm{mSv}$, it is necessary to perform appropriate protective measures;

- $1-10 \mathrm{mSv}$, protective measures are usually appropriate;

- below $1 \mathrm{mSv}$, the protective measures may be carried out especially when they are easy and sensible.

Contamination levels are categorized according to surface contamination by strong gamma and beta emitters and detachable form of alpha emitters. Strong gamma and beta emitters are e.g. ${ }^{58} \mathrm{Co},{ }^{60} \mathrm{Co},{ }^{106} \mathrm{Ru},{ }^{110 \mathrm{~m}} \mathrm{Ag},{ }^{134} \mathrm{Cs},{ }^{137} \mathrm{Cs},{ }^{144} \mathrm{Ce},{ }^{90} \mathrm{Sr}$, ${ }^{192} \mathrm{Ir}$ and ${ }^{226} \mathrm{Ra}$. Also ambient dose rate can be used as a categorizing indicator if the composition of radioactive contamination is known and the contamination covers large surface area. Table I shows the four contamination categories and the corresponding contamination indicators. If the ambient dose rate is at the level of normal background, the area is classified as "non-contaminated". 
Table I

Categories of surface contamination with radioactive deposition.

\begin{tabular}{llll}
\hline $\begin{array}{l}\text { Contamination } \\
\text { category }\end{array}$ & $\begin{array}{l}\text { Ambient dose rate } \\
(\mathbf{m i c r o S v} / \mathbf{h})\end{array}$ & $\begin{array}{l}\text { Strong gamma and beta } \\
\text { emitters together }\left(\mathbf{B q} / \mathbf{m}^{2}\right)\end{array}$ & $\begin{array}{l}\text { Alpha emitters, in } \\
\text { detachable form }\left(\mathbf{B q} / \mathbf{m}^{2}\right)\end{array}$ \\
\hline $\begin{array}{l}\text { Category I } \\
\text { Severly contaminated }\end{array}$ & $>100$ & over 40000000 & over 400000 \\
$\begin{array}{l}\text { Category II } \\
\text { Heavily contaminated }\end{array}$ & $10-100$ & $4000000-40000000$ & $40000-400000$ \\
$\begin{array}{l}\text { Category III } \\
\text { Contaminated }\end{array}$ & $1-10$ & $400000-4000000$ & $4000-40000$ \\
$\begin{array}{l}\text { Category IV } \\
\begin{array}{l}\text { Moderately contami- } \\
\text { nated }\end{array}\end{array} \quad<1$ & less than 400000 & less than 4000 \\
\hline $\begin{array}{l}\text { Non-contaminated } \\
\text { on the level of nor- }\end{array}$ & $\begin{array}{l}\text { no contamination at all or } \\
\text { mal background }\end{array}$ & $\begin{array}{l}\text { no contamination at all or } \\
\text { very low contamination }\end{array}$ \\
\hline
\end{tabular}

\section{Overall goal of protective measures in a radiological emergency}

All protective actions aim to keep the exposure of the population as small as possible, to minimize other harms caused by the event and to recover living conditions and the environment as near to normal as possible. Throughout the situation the need for protective actions will be constantly assessed. Also the need for changing, continuing or lifting the protective actions already taken will be considered. The assessment also takes into account how long the actions have lasted and how quickly the amount of radioactive materials in the environment is decreasing due to radioactive decay or decontamination measures.

The overall goal is that the residual radiation dose would not exceed the reference level of $20 \mathrm{mSv}$ during the first year, including all radiation exposure pathways. When assessing the radiation dose the exposure pathways to be taken into account are direct external exposure from an unshielded source, deposition or radioactive plume, inhaled radioactive substances, contamination of skin and radioactive substances in food and drinking water.

Management of the radiation situation may take years altogether. Throughout this period the primary goal is to reduce the annual dose to the population to a level that is seen as permanently acceptable

\section{Radiation protection criteria for different protective measures}

Intervention criteria proposed by STUK are divided into two guides; the first one concerning the early phase of an emergency and the second one dealing with the intermediate and late phases of an emergency. The guides include dose criteria and 
OILs for all main protective measures aiming at reducing population's and workers' exposure to radiation. This paper deals only with the criteria for population. Also triggers, not based on doses or OILs, to start protective measures around the domestic nuclear power plants are given in the guides.

The proposed guides deal with criteria for the following actions; urgent measures in the vicinity of nuclear power plants, sheltering indoors, partial sheltering indoors, lifting the sheltering, iodine prophylaxis for children and adults, rapid evacuation of people and lifting of evacuation, temporary and permanent relocation of people, control of access to contaminated area, actions concerning foodstuffs and feeding stuffs, restrictions of use of land and water areas, decontamination and other actions, and management of wastes. Some of the dose criteria and operational intervention levels of the proposed Finnish guides are given in Table II. Numerical values of OILs may still be changed during finalization of the guides.

Table II

Planned dose criteria and operational intervention levels for population in a nuclear or radiological emergency in Finland.

\begin{tabular}{|c|c|c|}
\hline Protective action & Dose criteria & Operational intervention level \\
\hline Sheltering indoors & $10 \mathrm{mSv} / 2$ days & $\begin{array}{l}\text { Ambient dose rate } 100 \mu \mathrm{Sv} / \mathrm{h} \\
\text { Concentration in air: } \\
\text { - alpha emitters } 1 \mathrm{~Bq} / \mathrm{m}^{3} \\
\text { - beta emitters } 500 \mathrm{~Bq} / \mathrm{m}^{3} \\
\text { - gamma emitters } 10000 \mathrm{~Bq} / \mathrm{m}^{3} \\
\text { Deposition: } \\
\text { - alpha emitters } 400000 \mathrm{~Bq} / \mathrm{m}^{2} \\
\text { - strong beta and gamma emitters } 40000000 \\
\mathrm{~Bq} / \mathrm{m}^{2}\end{array}$ \\
\hline $\begin{array}{l}\text { Partial sheltering } \\
\text { indoors }\end{array}$ & $1-10 \mathrm{mSv} / 2$ days & $\begin{array}{l}\text { Ambient dose rate } 10 \mu \mathrm{Sv} / \mathrm{h} \\
\text { Concentration in air: } \\
\text { - alpha emitters } 0,1 \mathrm{~Bq} / \mathrm{m}^{3} \\
\text { - beta emitters } 50 \mathrm{~Bq} / \mathrm{m}^{3} \\
\text { - gamma emitters } 1000 \mathrm{~Bq} / \mathrm{m}^{3} \\
\text { Deposition: } \\
\text { - alpha emitters } 40000 \mathrm{~Bq} / \mathrm{m}^{2} \\
\text { - strong beta and gamma emitters } 4000000 \\
\mathrm{~Bq} / \mathrm{m}^{2}\end{array}$ \\
\hline $\begin{array}{l}\text { Lifting the sheltering } \\
\text { indoors }\end{array}$ & $<10 \mathrm{mSv} /$ month & $\begin{array}{l}\text { Ambient dose rate }<10 \mu \mathrm{Sv} / \mathrm{h} \\
\text { Deposition: } \\
\text { - alpha emitters }<40000 \mathrm{~Bq} / \mathrm{m}^{2} \\
\text { - strong beta and gamma emitters }<4000000 \\
\mathrm{~Bq} / \mathrm{m}^{2}\end{array}$ \\
\hline Iodine prophylaxis & $\begin{array}{l}100 \mathrm{mGy} \text { to thyroid (adults) } \\
10 \mathrm{mGy} \text { to thyroid (chil- } \\
\text { dren) }\end{array}$ & $\begin{array}{l}\text { Ambient dose rate: } \\
\text { - } 100 \mu \mathrm{Sv} / \mathrm{h} \text { for adults } \\
\text { - } 10 \mu \mathrm{Sv} / \mathrm{h} \text { for children } \\
\mathrm{I}-131 \text { concentration in air: } \\
\text { - adults } 10000 \mathrm{~Bq} / \mathrm{m}^{3} \\
\text { - children } 1000 \mathrm{~Bq} / \mathrm{m}^{3}\end{array}$ \\
\hline Evacuation & $20 \mathrm{mSv} /$ week & $\begin{array}{l}\text { Sheltering indoors lasts over } 2 \text { days } \\
\text { Ambient dose rate } 100 \mu \mathrm{Sv} / \mathrm{h} \\
\text { Deposition: } \\
\text { - alpha emitters } 400000 \mathrm{~Bq} / \mathrm{m}^{2} \\
\text { - strong beta and gamma emitters } 40000000 \\
\mathrm{~Bq} / \mathrm{m}^{2}\end{array}$ \\
\hline
\end{tabular}




\begin{tabular}{|c|c|c|}
\hline Lifting evacuation & $\begin{array}{l}<10 \mathrm{mSv} / \mathrm{month} \text { and decreas- } \\
\text { ing quickly }\end{array}$ & $\begin{array}{l}\text { Ambient dose rate }<10 \mu \mathrm{Sv} / \mathrm{h} \text { and decresing } \\
\text { quickly } \\
\text { Deposition: } \\
\text { - alpha emitters }<40000 \mathrm{~Bq} / \mathrm{m}^{2} \\
\text { - strong beta and gamma emitters }<4000000 \\
\mathrm{~Bq} / \mathrm{m}^{2}\end{array}$ \\
\hline Temporary relocation & $\begin{array}{l}10 \mathrm{mSv} / \text { month } \\
\text { (Reference level } 20 \mathrm{mSv} / \\
\text { first year) }\end{array}$ & $\begin{array}{l}\text { Ambient dose rate } 10 \mu \mathrm{Sv} / \mathrm{h} \\
\text { Deposition: } \\
\text { - alpha emitters } 40000 \mathrm{~Bq} / \mathrm{m}^{2} \\
\text { - strong beta and gamma emitters } 4000000 \\
\mathrm{~Bq} / \mathrm{m}^{2}\end{array}$ \\
\hline Permanent relocation & $\begin{array}{l}50 \mathrm{mSv} / \text { year } \\
1000 \mathrm{mSv} \text { in lifetime }\end{array}$ & Lifetime ambient dose rate $5 \mu \mathrm{Sv} / \mathrm{h}$ \\
\hline $\begin{array}{l}\text { Self-decontamination } \\
\text { of people }\end{array}$ & & $\begin{array}{l}\text { Dose rate close to the skin }<0.5 \mu \mathrm{Sv} / \mathrm{h} \text { over the } \\
\text { prevailing dose rate at the monitoring place } \\
\text { Skin contamination: } \\
\text { - alpha emitters } 0.4-100 \mathrm{~Bq} / \mathrm{cm}^{2} \\
\text { - strong beta and gamma emitters } 4-1000 \mathrm{~Bq} / \\
\mathrm{cm}^{2}\end{array}$ \\
\hline $\begin{array}{l}\text { Controlled decontami- } \\
\text { nation of people }\end{array}$ & & $\begin{array}{l}\text { Dose rate close to the skin }>0.5 \mu \mathrm{Sv} / \mathrm{h} \text { over the } \\
\text { prevailing dose rate at the monitoring place } \\
\text { Skin contamination: } \\
\text { - alpha emitters }>100 \mathrm{~Bq} / \mathrm{cm}^{2} \\
\text { - strong beta and gamma emitters }>1000 \mathrm{~Bq} / \mathrm{cm}^{2}\end{array}$ \\
\hline $\begin{array}{l}\text { Sending a contaminat- } \\
\text { ed person to hospital }\end{array}$ & & $\begin{array}{l}\text { Dose rate close to the skin }>2 \mu \mathrm{Sv} / \mathrm{h} \text { over the } \\
\text { prevailing dose rate at the monitoring place } \\
\text { Skin contamination: } \\
\text { - alpha emitters }>1000 \mathrm{~Bq} / \mathrm{cm}^{2} \\
\text { - strong beta and gamma emitters }>10000 \mathrm{~Bq} / \\
\mathrm{cm}^{2}\end{array}$ \\
\hline Control of access & & $\begin{array}{l}\text { Ambient dose rate }>100 \mu \mathrm{Sv} / \mathrm{h} \\
\text { Deposition: } \\
\text { - alpha emitters } 400000 \mathrm{~Bq} / \mathrm{m}^{2} \\
\text { - strong beta and gamma emitters } 40000000 \\
\mathrm{~Bq} / \mathrm{m}^{2}\end{array}$ \\
\hline
\end{tabular}

\section{Links between the dose criteria and operational intervention levels}

Criterion to start some protective action is normally based on estimated dose to be received by an individual. The dose is either an effective dose or an organ dose (equivalent dose or absorbed dose). These doses are not directly measurable and therefore directly measurable quantities are needed in operational emergency life. The quantity may be ambient dose rate, activity concentration, or surface activity. In order to convert effective or equivalent dose to a measurable unit, composition of the radioactive contamination must be known. Composition of the contamination depends on the source of radioactive substances and the type of incident. Normally it is not possible to know the composition and therefore some presumptions are necessary when OILs are derived. In the guides of STUK, the contamination 
is assumed to contain several radionuclides, and the following rough procedure is used in deriving the operational intervention levels:

- dose criterion is first converted into ambient dose (equivalent) rate;

- because there might be several contributors to the dose, the operational intervention level, in $\mu \mathrm{Sv} / \mathrm{h}$, is chosen as less than half of the calculated value $(\rightarrow$ dose rate OIL);

- ambient dose rate is converted to airborne concentration criterion for alpha, beta and gamma emitters by using the committed effective dose conversion factor of the most restrictive nuclide via inhalation $\left({ }^{239} \mathrm{Pu}\right.$ for alpha emitters, ${ }^{90} \mathrm{Sr}$ for beta emitters and ${ }^{137} \mathrm{Cs}$ for gamma emitters, Council Directive 96/29/ EURATOM, 1996) and the average breathing rate $(\rightarrow$ airborne concentration OIL);

- airborne concentration is converted to surface activity criterion by using the resuspension factor of $6 \times 10^{-6} \mathrm{~m}^{-1}$ for alpha emitting radionuclides $\left({ }^{239} \mathrm{Pu}\right)$ in detachable form $(\rightarrow$ surface activity OIL);

- for strong beta and gamma emitting radionuclides, the surface activity criterion is derived by assuming that all activity is on an infinite surface (ground deposition) and using dose conversion factor of ${ }^{137} \mathrm{Cs}$ ( $\rightarrow$ surface activity OIL).

Of course this approach is very coarse and the derived OILs should be used only if real measurement values are not available. The use of ambient dose equivalent as a surrogate for effective dose equivalent is conservative, but in this application it is useful because the derivation of OILs is quite coarse anyway, as shown in the following example for derivation of measurable OILs for sheltering indoors:

- dose criterion for sheltering indoors: $10 \mathrm{mSv} / \mathbf{2}$ days as effective dose;

- ambient dose rate: $10^{-3} \mathrm{~Sv} /(2 \times 24) \mathrm{h}=2.08 \times 10^{-4} \mathrm{~Sv} / \mathrm{h}=208 \mu \mathrm{Sv} / \mathrm{h}$;

- dose rate OIL: because there might be several contributors to the dose, the operational intervention level, in $\mu \mathrm{Sv} / \mathrm{h}$, is chosen as less than half of the calculated value $\rightarrow \mathrm{OIL}$ is $\mathbf{1 0 0} \boldsymbol{\mu S v} / \mathbf{h}$;

- air concentration OILs: breathing rate $1,2 \mathrm{~m}^{3} / \mathrm{h}$, dose rate in air $2.08 \times 10^{-4} \mathrm{~Sv} / \mathrm{h}$,

- alpha $\left({ }^{239} \mathrm{Pu}\right)$ : dose factor (inhalation, worker) $4.7 \times 10^{-5} \mathrm{~Sv} / \mathrm{Bq}$, concentration in air $=\left(2.08 \times 10^{-4} \mathrm{~Sv} / \mathrm{h}\right) /\left(4.7 \times 10^{-5} \mathrm{~Sv} / \mathrm{Bq} \times 1.2 \mathrm{~m}^{3} / \mathrm{h}\right)=3.5 \mathrm{~Bq} / \mathrm{m}^{3}$; because there might be several contributors to the dose, the operational intervention level, in $\mathrm{Bq} / \mathrm{m}^{3}$, is chosen as less than half of the calculated value $\rightarrow$ OIL is $1 \mathbf{B q} / \mathbf{m}^{3}$;

- beta $\left({ }^{90} \mathrm{Sr}\right)$ : dose factor (inhalation, worker) $1.5 \times 10^{-7} \mathrm{~Sv} / \mathrm{Bq}$, concentration in air $=\left(2.08 \times 10^{-4} \mathrm{~Sv} / \mathrm{h}\right) /\left(1.5 \times 10^{-7} \mathrm{~Sv} / \mathrm{Bq} \times 1.2 \mathrm{~m}^{3} / \mathrm{h}\right)=1155 \mathrm{~Bq} / \mathrm{m}^{3} ;$ because there might be several contributors to the dose, the operational intervention level, in $\mathrm{Bq} / \mathrm{m}^{3}$, is chosen as less than half of the calculated value $\rightarrow$ OIL is $500 \mathrm{~Bq} / \mathrm{m}^{3}$;

- gamma $\left({ }^{137} \mathrm{Cs}\right)$ : dose factor (inhalation, worker) $6.7 \times 10^{-9} \mathrm{~Sv} / \mathrm{Bq}$, concentration in air $=\left(2.08 \times 10^{-4} \mathrm{~Sv} / \mathrm{h}\right) /\left(6.7 \times 10^{-9} \mathrm{~Sv} / \mathrm{Bq} \times 1.2 \mathrm{~m}^{3} / \mathrm{h}\right)=25800 \mathrm{~Bq} / \mathrm{m}^{3}$; 
because there might be several contributors to the dose, the operational intervention level, in $\mathrm{Bq} / \mathrm{m}^{3}$, is chosen as less than half of the calculated value $\rightarrow$ OIL is $10000 \mathrm{~Bq} / \mathrm{m}^{3}$;

- surface activity OILs: in case of strong gamma and beta emitters, the exposure is caused by direct radiation from the deposition (all activity still on the surface), in case of alpha emitters, exposure is caused by inhalation (radionulides in air due to resuspension), resuspension factor $6 \times 10^{-6} \mathrm{~m}^{-1}$,

- alpha $\left({ }^{239} \mathrm{Pu}\right)$ : dose factor (inhalation, worker) $4.7 \times 10^{-5} \mathrm{~Sv} / \mathrm{Bq}$, surface activity $=$ concentration $/$ resuspension factor $=\left(3.5 \mathrm{~Bq} / \mathrm{m}^{3}\right) /\left(6 \times 10^{-6} \mathrm{~m}^{-1}\right)=$ $5.8 \times 10^{5} \mathrm{~Bq} / \mathrm{m}^{2}$; because there might be several contributors to the dose, the operational intervention level, in $\mathrm{Bq} / \mathrm{m}^{2}$, is chosen about half of the calculated value $\rightarrow$ OIL is $400000 \mathrm{~Bq} / \mathrm{m}^{2}$;

- strong gamma or beta $\left({ }^{137} \mathrm{Cs}\right)$ : dose rate factor $2.5 \times 10^{-12}(\mathrm{~Sv} / \mathrm{h}) /\left(\mathrm{Bq} / \mathrm{m}^{2}\right)$, surface activity $=$ dose rate in air/dose rate factor $=\left(2.08 \times 10^{-4} \mathrm{~Sv} / \mathrm{h}\right) /$ $\left(2.5 \times 10^{-12}(\mathrm{~Sv} / \mathrm{h}) /\left(\mathrm{Bq} / \mathrm{m}^{2}\right)\right)=83.2 \times 10^{6} \mathrm{~Bq} / \mathrm{m}^{2}$; because there might be several contributors to the dose, the operational intervention level, in $\mathrm{Bq} / \mathrm{m}^{2}$, is chosen about half of the calculated value $\rightarrow$ OIL is $40000000 \mathrm{~Bq} / \mathbf{m}^{2}$.

Acknowledgements. The draft guides presented in this paper have been prepared by a STUK working group: K. Aakko, H. Aaltonen, R. Hänninen, T. K. Ikäheimonen and M. Markkanen.

\section{REFERENCES}

ICRP Publication 103 (2007) The 2007 Recommendations of the International Commission on Radiological Protection, Ann. ICRP 37 (2-4).

ICRP Publication 109 (2009a) Application of the Commission's Recommendations for the Protection of People in Emergency Exposure Situations, Ann. ICRP 39 (1).

ICRP Publication 111 (2009b) Application of the Commission's Recommendations to the Protection of People Living in Long-term Contaminated Areas after a Nuclear Accident or a Radiation Emergency, Ann. ICRP 39 (3).

STUK (2011) STUK VAL-GUIDES 1 AND 2: Protective measures in early and intermediate phases of a nuclear or radiological emergency (drafts not published).

Council Directive 96/29/EURATOM (1996) Laying down basic safety standards for the protection of the health of workers and the general public against the dangers arising from ionizing radiation, Official Journal of the European Communities, No L 159. 